\title{
Study protocol: a double blind placebo controlled trial examining the effect of domperidone on the composition of breast milk [NCT00308334]
}

\author{
Marsha L Campbell-Yeo*1,2, Alexander C Allen ${ }^{1,3}$, K S Joseph ${ }^{3}$, \\ Joyce M Ledwidge ${ }^{1}$, Victoria M Allen ${ }^{3}$ and Kent C Dooley ${ }^{4}$
}

\begin{abstract}
Address: ${ }^{1}$ Neonatal Intensive Care Unit, IWK Health Centre and Dalhousie University, Halifax, Nova Scotia, Canada, ${ }^{2}$ Doctoral Candidate, McGill University, Quebec, Canada, ${ }^{3}$ the Perinatal Epidemiology Research Unit, Departments of Obstetrics \& Gynecology and Pediatrics, IWK Health Centre and Dalhousie University, Halifax, Nova Scotia, Canada and ${ }^{4}$ Laboratory Services, IWK Health Centre and Dalhousie University, Halifax, Nova Scotia, Canada
\end{abstract}

Email: Marsha L Campbell-Yeo* - Marsha.campbellyeo@iwk.nshealth.ca; Alexander C Allen - Alexander.allen@dal.ca; K S Joseph - KSJoseph@dal.ca; Joyce M Ledwidge - Joyce.Ledwidge@iwk.nshealth.ca; Victoria M Allen - vmallen@dal.ca; Kent C Dooley - kent.dooley@iwk.nshealth.ca

* Corresponding author

\section{Published: 23 May 2006}

BMC Pregnancy and Childbirth 2006, 6:17 doi:10.1186/1471-2393-6-17
Received: II April 2006

Accepted: 23 May 2006

This article is available from: http://www.biomedcentral.com/I47/-2393/6/17

(c) 2006 Campbell-Yeo et al; licensee BioMed Central Ltd.

This is an Open Access article distributed under the terms of the Creative Commons Attribution License (http://creativecommons.org/licenses/by/2.0), which permits unrestricted use, distribution, and reproduction in any medium, provided the original work is properly cited.

\begin{abstract}
Background: Domperidone, a drug that enhances upper gastric motility, is an anti-dopaminergic medication that also elevates prolactin levels. It has been shown to safely increase the milk supply of lactating women. To date, researchers have analyzed the effects of domperidone on lactating woman with respect to the quantity of their milk production, adverse effects, and drug levels in the breast milk. However, the effect of domperidone on the macronutrient composition of breast milk has not been studied and current guidelines for fortification of human milk for premature infants do not distinguish between those women using or those not using domperidone. The purpose of this study is to evaluate the effect of domperidone (given to lactating mothers of very preterm infants) on the macronutrient composition of breast milk.

Methods/Design: Mothers of infants delivered at less than 3 I weeks gestation, who are at least 3 weeks postpartum, and experiencing lactational failure despite non-pharmacological interventions, will be randomized to receive domperidone ( $10 \mathrm{mg}$ three times daily) or placebo for a 14-day period.

Breast milk samples will be obtained the day prior to beginning treatment and on days 4,7 and I4. The macronutrient (protein, fat, carbohydrate and energy) and macromineral content (calcium, phosphorus and sodium) will be analyzed and compared between the two groups. Additional outcome measures will include milk volumes, serum prolactin levels (measured on days 0,4 , and 10), daily infant weights and breastfeeding rates at 2 weeks post study completion and at discharge. Forty-four participants will be recruited into the study. Analysis will be carried out using the intention to treat approach.

Discussion: If domperidone causes significant changes to the nutrient content of breast milk, an alteration in feeding practices for preterm infants may need to be made in order to optimize growth, nutrition and neurodevelopment outcomes.
\end{abstract}




\section{Background}

During the past two decades, significant advances in medical technology have contributed to the increased survival of preterm, very low birth weight infants. As mortality rates have declined, the focus has shifted to decreasing morbidity and length of hospital stay for these high-risk infants. Nutritional care is one area with great potential for improvement. There continue to be many unanswered questions as to what constitutes optimal nutrient intake for the extremely preterm neonate. Although the current literature states that fortified human breast milk is most desirable [1-6], the optimal macronutrient composition of prepared fortifiers continues to be studied [7]. Also, the shift from formula feeding of preterm infants to human breast milk has caused an increase in mothers of preterm infants providing expressed breast to their babies over prolonged periods.

Many mothers of very preterm infants experience difficulty maintaining milk production over several months, and hence medications such as domperidone are often recommended to help augment milk supply. Such medications increase maternal prolactin levels and have been shown to significantly increase the quantity of breast milk a lactating woman produces [8-18]. Higher prolactin levels have been linked to accelerated decline in protein levels in term breast milk $[19,21]$. However, there is a paucity of information in the literature, on the effect of domperidone on the macronutrient content of breast milk. Although pharmacological augmentation of breast milk volume is valuable, carefully conducted quantitative studies are required to assess the effect of such medication on human breast milk composition including protein, fat and other constituents. We, therefore, designed a study to determine the effect of domperidone on the macronutrient (protein, fat, and energy) and macromineral (calcium, phosphorus, and sodium) content of breast milk among mothers of very preterm infants.

\section{Summary of literature review a. Advantages of human breast milk}

Breast milk is generally considered to be the optimal form of nutrition for all infants regardless of gestational age $[1,2]$. Preterm infants have better outcomes if they receive human breast milk during the first months after birth. Human breast milk provides both nutritive and nonnutritive benefits to preterm infants. Nutritive benefits include a whey predominant protein source, which is more easily digested and promotes more rapid gastric emptying. Human milk is also a source of the very long chain fatty acids, which are important components of brain and red cell membranes. Nonnutritive advantages include psychological benefits of maternal-infant bonding, improved gastrointestinal outcomes, reduced risk of atopic eczema, and fewer systemic infections during initial hospitaliza- tion, [3-7, 24-28] as well as, improved psychomotor development [26-29].

\section{b. Expressed breast milk}

Increasingly, mothers of premature babies being cared for in neonatal intensive care units are asked to provide expressed human breast milk for their babies. Most mothers express a strong desire to provide breast milk for their infant and verbalize positive feelings about being able to do something to help their ill baby. However, many mothers of very preterm infants find it difficult to provide adequate amounts of expressed breast milk to meet their baby's needs over prolonged periods of time. Stress related to the hospitalization, concerns related to the increased risk of mortality and morbidity, separation, and lack of infant suckling may contribute to decreased milk production [33]. Decreased milk production among mothers of very preterm infants expressing breast milk can occur as early as two weeks postpartum, although such problems typically peak between four and six weeks postpartum $[8,33]$.

\section{c. Physiology of lactation}

The initiation of lactation (lactogenesis) is a natural process that is based on a complex interaction of hormones. Changes in estrogen and progesterone during pregnancy alter the morphologic structure of breast tissue. Increasing levels of the hormone prolactin is key in the initiation and maintenance of lactation [34,35] and may play a role in the control of electrolyte composition $[20,21]$ and alteration in amino acid concentration [19] of mature human breast milk. A significant increase in lactogenesis occurs following delivery with the concurrent decline in estrogen and progesterone. In addition, the tactile stimulus by the suckling baby causes a release of prolactin from the pituitary, which stimulates milk flow. This suckling induced prolactin release is a reflex related to hypothalamic serotoninergic neuron activation, accompanied by a concomitant increase of dopamine turn over [34,35]. Babies delivered at less than 32 weeks gestation are not able to effectively coordinate sucking, swallowing and breathing [36]. The lack of effective suckling that is associated with the delivery of a preterm baby as well as maternal stress, infection, or fatigue can lead to difficulties maintaining lactation $[8,33]$.

\section{d. Non-pharmacological interventions to enhance human breast milk production}

Non pharmacological measures such as added emotional support, kangaroo care/skin to skin, compressing and massage, relaxation techniques, expressing breast milk at the baby's bedside, increasing pumping times, and alterations in mechanical expression contribute to a variable level of success in augmenting milk production [9,37]. For those mothers whose milk production is refractory to 
non-pharmacological interventions, and who verbalize a continued desire to provide expressed breast milk, the use of pharmacological intervention may be recommended.

\section{e. Pharmacological interventions}

The administration of an anti-dopaminergic drug, such as metoclopramide or domperidone has been shown to yield positive results. Endogenous dopamine has a physiological inhibitory role in the control of prolactin release. Therefore, the administration of a dopamine inhibitor increases plasma prolactin levels and induces lactogenesis [9]. Metoclopramide, a central dopamine antagonist, has been most widely studied and proven to be highly efficacious in augmenting milk supply [8,10-14]. However, reports indicate that it crosses the blood brain barrier, and is secreted in significant amounts in the breast milk [12]. As well, animal studies have reported dopamine mediated responses in the offspring of nursing rats [38].

\section{f. Why choose domperidone?}

Both metaclopramide and domperidone are antidopaminergic drugs. Both induce lactation by inhibiting endogenous dopamine and thereby increasing plasma prolactin levels. Domperidone is a newly developed antiemetic with no structural relationship to the phenothiazine anti-emetics and metoclopramide; it is structurally related to the neuroleptic drug droperidol. Domperidone is a dopamine antagonist in vitro; it binds strongly to the dopamine (DA) receptors of the striatal area [40]. It is felt the domperidone inhibits dopamine receptors at either the level of the anterior pituitary median eminence or at the tuberoinfundibular systems, both of which are outside the blood brain barrier. This differs significantly from metoclopramide, which inhibits dopamine (DA) centrally [9]. Domperidone is less lipid soluble, has a higher molecular weight and has lower protein binding as compared with metoclopramide [84]. These characteristics may also prevent domperidone from crossing the blood brain barrier, thus causing less extra pyramidal effects that are more commonly reported with the use of metoclopramide.

Thus, domperidone, a peripheral dopamine antagonist, may be safer than metoclopramide [39]. Drug levels of domperidone in breast milk are also significantly lower than metoclopramide $(\mathrm{p}<0.05)[15,16]$. Studies have shown that breast milk samples taken from women receiving either a $10 \mathrm{mg}$ dose of domperidone or a $10 \mathrm{mg}$ dose of metoclopramide contained $10.3 \mathrm{ng} / \mathrm{ml}$ of domperidone and $68.5 \mathrm{ng} / \mathrm{ml}$ of metoclopramide $(\mathrm{p}<0.05)$ [16]. Domperidone has been shown to significantly increase milk production without evidence of adverse effects in the infant [15-18]. Domperidone has been shown to raise the serum prolactin level in non-lactating women from 8.1 to $110.9 \mathrm{ng} / \mathrm{ml}$ after one $20 \mathrm{mg}$ dose
[40]. In a double-blind placebo controlled trial, 32 mothers of full term infants experiencing failure of lactogenesis were randomized to receive either domperidone $(10 \mathrm{mg}$ TID) or placebo. Prolactin levels were reported as significantly higher after the $2^{\text {nd }}$ day of treatment in the domperidone group $(\mathrm{p}<0.01)$. The mean daily milk yield was also increased significantly in the domperidone group ( $\mathrm{P}$ $<0.01$ ), with a corresponding higher infant weight gain [18]. In a small double blind, randomized controlled trial $(\mathrm{n}=16)$, a 7 day course of domperidone (10 mg TID) given to mothers of preterm infants experiencing insufficient milk production resulted in a significantly increased milk supply $(\mathrm{P}<0.05)$, low levels of drug detected in breast milk ( $<0.2 \mathrm{mcg} / \mathrm{kg} / \mathrm{d}$ ) and significantly higher maternal prolactin level when compared to the placebo group [17]. No infant or maternal side effects were reported in the above trials. Both the Canadian and American Academy of Pediatrics have approved the use of domperidone for breast-feeding mothers [41].

\section{g. Fortification of human breast milk}

Despite the numerous advantages of human breast milk, the exclusive feeding of human breast milk to premature infants has been associated with lower rates of growth, nutritional deficits, and prolonged hospital stays [42-51]. Commercial formulas for preterm infants have been designed to meet the nutritional needs of such infants but cannot provide the infant with the advantages of human milk [3-7,22-32]. Therefore, it is generally recommended that breast milk feeds for preterm infants be fortified with a commercially available human milk fortifier (HMF) $[2,7,52,53]$. The inadequate intake of protein, energy, calcium, and phosphorus related to unfortified breast milk has been cited as the main reason for the need for fortifiers [42-50,55-58]. Infant fortifiers provide supplemental amounts of calories, protein, vitamins, minerals and trace elements to human breast milk in order to best meet the nutritional needs of the preterm infants.

Preterm infants are born with low skeletal stores of calcium and phosphate. They have increased requirements for these minerals in order to ensure adequate postnatal skeletal growth. Poor radiological bone mineralization, rickets and fractures have been described in premature infants receiving breast alone $[55,56,58]$. Supplementation of calcium and phosphorous has been shown to normalize biochemical indices, serum calcium, and serum phosphorus, as well as normal urinary excretion of calcium and phosphorous [59-61]. Serum sodium levels also normalize following supplementation [57].

Protein and energy supplementation has been associated with improved rates of weight gain and better indices of protein nutritional status [49]. The Cochrane review on protein supplementation states that protein supplementa- 
tion of preterm mothers milk increases short-term weight gain: weighted mean difference $3.6 \mathrm{~g} / \mathrm{kg} /$ day, $95 \%$ CI 2.4 to $4.8 \mathrm{~g} / \mathrm{kg} /$ day, linear growth $0.28 \mathrm{~cm} /$ week, $95 \%$ CI 0.18 to $0.38 \mathrm{~cm} /$ week, and head growth $0.15 \mathrm{~cm} /$ week, $95 \%$ CI 0.06 to $0.23 \mathrm{~cm} /$ week. Blood urea levels also increase with protein supplementation $1.0 \mathrm{mmol} / \mathrm{l}, 95 \%$ CI 0.8 to 2.1 $\mathrm{mmol} / \mathrm{l}$ [62]. Current supplemental feeding practices are calculated based on anticipated macronutrient and electrolyte composition of preterm mother's milk that is not being augmented by medication.

\section{h. Breast milk composition}

Human breast milk composition is widely variable both within and between breast-feeding mothers [63]. Variation in macronutrient composition can occur at various feeding times throughout the day or night and also at the beginning and end of a feed [64]. These variations have been reported to be greater in mothers of preterm infants providing expressed breast milk. Measuring samples taken from pooled 24-hour collections may limit the degree of variability reported. Variation in the composition of human breast milk has been associated with the diagnosis of either sporadic or chronic mastitis. The sodium content of the breast milk is the constituent most profoundly affected [66].

The composition of preterm mother's milk also differs from that of term mother's milk [67-69]. Although protein levels are initially higher in preterm breast milk, the natural temporal decline of protein content creates a nutritional deficit when compared to the needs of the preterm infant [5]. Studies show that there is a decline in protein content following delivery, while fat, lactose and energy content increases. These trends are more pronounced during the first 3 weeks and are greatest in the preterm group [64]. In a more recent study, random spot samples of breast milk from mothers of premature infants were analyzed to estimate macronutrient variability. Although fat content was highly variable within and between individuals, it remained fairly constant throughout lactation. Protein was less variable but was found to decrease significantly throughout the first four weeks of lactation $(\mathrm{r}=-0.45, \mathrm{p}<0.001)$, then continued to fall at a slower rate of decline over time and with increased volumes of breast milk [70]. Several studies have reported similar findings $[67,70-74]$.

Maas [74] studied the effects of gestational age (GA), postnatal age (PNA), and post-menstrual (PMA = GA+PNA) on the macronutrient composition of very preterm mothers milk. Total nitrogen, fat, lactose and carbohydrate concentrations, energy density and 24-hour volume were determined from 282 (24 hour) samples collected (day 755) from seventy mothers of premature infants (25-29 weeks gestation) [74]. The major findings of the study were that developmental changes in milk composition are largely determined by PNA, minimally by GA and not at all by PMA. Milk volume $(24 \mathrm{~h})$ itself did not show a dependence on GA, PNA or PMA. When volume was used as a time varying covariate in the analysis, total nitrogen content decreased while lactose and carbohydrate content increased when 24-hour milk volume increased. These findings were in accordance with the literature $[70,71,73]$.

There have been two studies examining the effect of metoclopramide on macronutrient content and sodium content of term mother's milk. When term breast milk samples from primiparous women taking metoclopramide were compared to samples from a similar group taking a placebo, the expected decline in protein content occurred at an accelerated rate in the treatment group [19]. Sodium concentration in term human breast milk was compared in a smaller study using a similar design to determine the effect of metoclopramide. No significant differences were detected between groups. The small sample size $(\mathrm{n}=22)$ and lack of data regarding calcium and phosphorus levels warrant further investigation in relation to preterm milk composition [21]. Since domperidone differs in structure and mechanism of action from metoclopramide and since studies evaluating metoclopramide's effect on breast milk composition have been limited to term mother's milk, our study is both warranted and necessary to ensure optimal infant nutrition.

\section{Hypothesis}

The macronutrient composition (protein, fat and calories) of human breast milk will be significantly altered by the administration of domperidone.

\section{Methods/Design \\ a. Objectives}

The intent of this study is to evaluate the effect of domperidone on the macronutrient composition of breast milk among mothers of preterm infants. Potential changes in protein, fat, lactose, energy, calcium, phosphorus and sodium content in expressed breast milk will be assessed. Secondary objectives include assessment of the effect of domperidone on breast milk volume, prolactin level, daily infant weight, and breastfeeding rates 2 weeks after treatment completion and at discharge.

\section{b. Study design}

We propose to carry out a randomized double-blind placebo-controlled study comparing the effect of domperidone use on the macronutrient composition of preterm mother's milk.

\section{c. Study population}

The source population consists of mothers of preterm infants delivered at less than 31 weeks gestational age 
admitted to the Neonatal Intensive Care Unit at the IWK Health Centre who are providing expressed breast milk to their infants and who experience lactational failure three weeks after delivery.

\section{d. Inclusion criteria}

i. Mother of an infant born less than 31 weeks gestation

ii. Women mechanically expressing breast milk using a double collecting system

iii. Experiencing lactation failure indicated by at least one of the following:

A decreasing milk supply (by greater than 30 percent from peak volume based on maternal account)

An inability to provide adequate breast milk to meet the daily nutritional intake of their infant

iv. Women who have had little or no improvement in milk production following education/counseling with a lactation consultant/Neonatal Intensive Care nurse with respect to non-pharmacological techniques.

v. Postpartum period equal to or greater than three weeks.

\section{e. Selection criteria for study subjects}

Women who meet the inclusion criteria will be approached by the study investigator/nurse, informed of the study. Signed written informed consent will be obtained.

\section{f. Exclusion criteria}

i. Participants receiving any medication known to alter the effect of domperidone (e.g. cimetidine, ranitidine, famotidine, and nizatidine) or medication that interacts with domperidone (e.g. haloperidol, lithium).

\section{ii. Experiencing mastitis}

iii. Having a chronic or debilitating illness.

iv. Previous breast surgery

v. Having a known lactose intolerance

\section{Allocation of participants to the trial groups - see figure I \\ Randomization}

Eligible and consenting woman will be randomized in blocks of four. Pharmacy staff will randomly (using a computer based code) assign mothers to receive either domperidone, $10 \mathrm{mg}$ orally three times daily $[17,38]$ or placebo for a two week period. Mothers of infants $>3$ but
$<4$ weeks postpartum will be randomized separately from those $\geq 4$ weeks postpartum in order to ensure identical proportions within the domperidone and placebo groups (i.e. randomizations will be stratified by postpartum duration at study entry). Participants will receive their 2week drug or placebo supply following enrollment. They will be provided with instruction related to self-administration and asked to return the medication vial and any unused medication at the completion of the two-week period. The study nurse/investigators will be in close contact with the mothers and review instruction related to medication on study days 4,7 , and 14 .

\section{What are the proposed methods of protecting against sources of bias?}

The double blind study design in which participants, neonatal staff, and study personnel will be blinded to group enrollment will ensure that non-domperidone related intervention effects and information collection is similar between the drug and placebo groups. In order to have similar presentation and appearance of domperidone and placebo, domperidone tablets will be crushed and mixed with lactose. The resulting powder will be placed in clear capsules. Plain lactose powder will also be placed in clear capsules to act as the placebo. Participants will receive a two-week supply of either domperidone or placebo following randomization at no cost to them. Measured prolactin levels will not be made available until the completion of the study period.

\section{What is the proposed duration of treatment?}

The treatment period begins following randomization. It consists of day 0 on which baseline measurements will be taken and recorded, and a 14-day treatment period during which domperidone (10 mg $\times 3 /$ daily) or placebo (3/ daily) is administered.

\section{What is the proposed frequency and duration of follow-up?}

Breast milk samples will be obtained on day $0,4,7$, and 14. Serum prolactin levels will be collected on days 0,4 , and 14. Infant weights will be measured daily. Each participant will be asked questions regarding breast-feeding two weeks following discontinuation of the treatment and at discharge.

\section{What are the proposed outcome measures?} a. Primary outcome

The protein levels from breast milk, collected on days 0,4 , 7 , and 14 will be compared, between the two groups (taking into consideration the expected rate of decline associated with increasing postpartum days). 


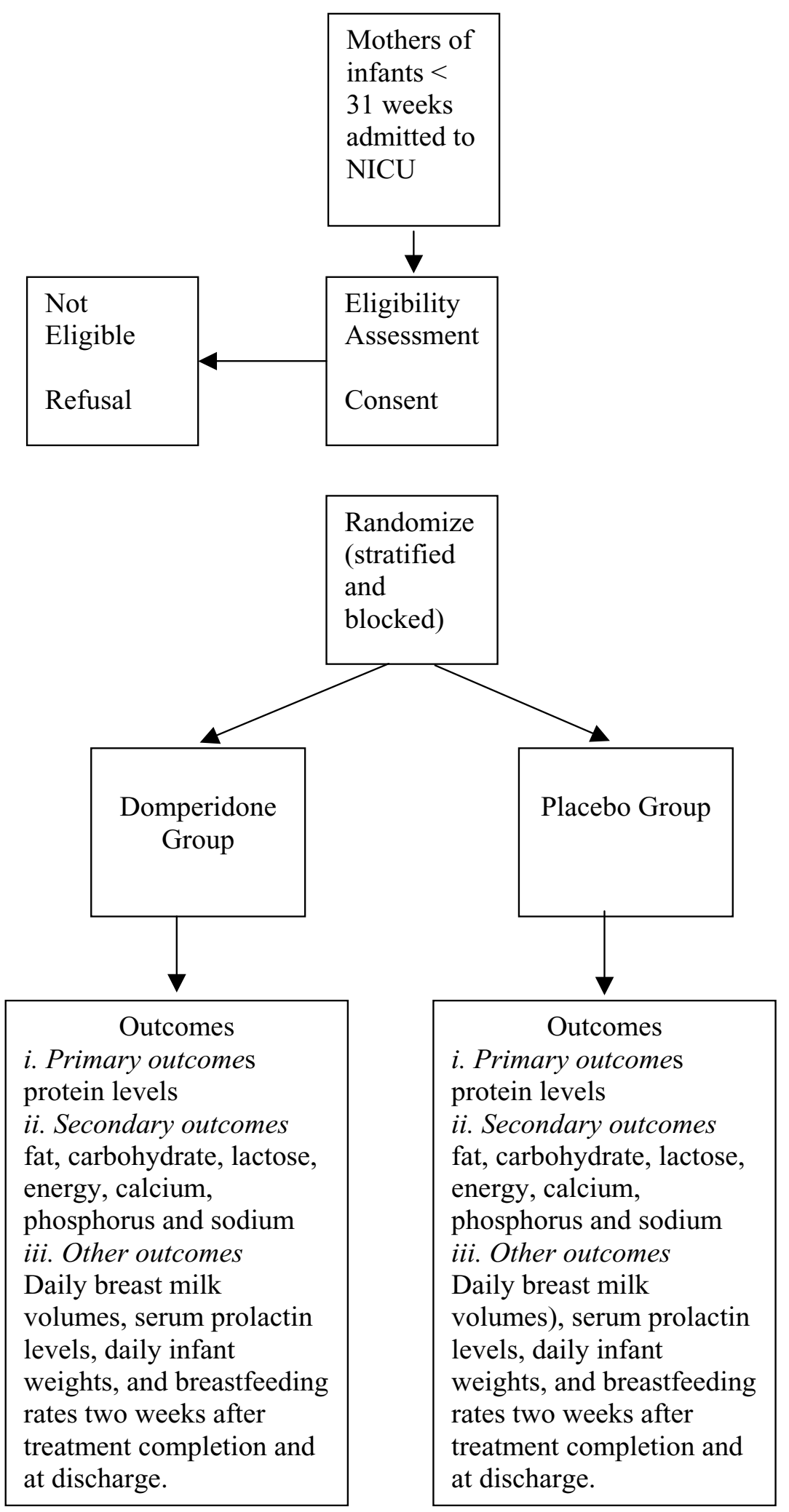

Figure I

Allocation of Participants to the Trial Groups. 


\section{b. Secondary outcomes}

The fat, carbohydrate, lactose, energy, calcium, phosphorus and sodium content of breast milk, collected on days $0,4,7$, and 14 , will be compared between domperidone and placebo groups.

\section{c. Other outcomes}

Daily breast milk volumes (if the infant breast feeds, volume will be estimated using pre and post feeding weights), serum prolactin levels, daily infant weights, and breastfeeding rates two weeks after treatment completion and at discharge.

\section{Sample size}

Sample size was calculated using a 2-sided test, an alpha error of 0.05 and a power of 80 percent. Based on the medical literature and prior clinical understanding, we designed the study to detect as significant a 20 percent or greater change in protein content (in the domperidone group relative to the placebo group). We will also have sufficient power to detect a 20 percent or greater change in fat content and a 10 percent or greater change in energy content, if such differences are in fact caused by domperidone. Means and standard deviation values for protein, fat and energy content used in the sample size calculation were obtained from a recent, authoritative publication on the breast milk content of preterm human milk [74]. Based on this calculation our study will recruit 44 participants, 22 assigned to the domperidone group and 22 to the placebo group.

\section{What is the planned recruitment rate?}

In the year 2000, 58 surviving infants less than 31 weeks gestation were admitted to the Neonatal Intensive Care Unit. Of these 20-25 percent were multiple births. Breastfeeding initiation rates are 80-85 percent in our nursery. Due to the lack of information regarding the incidence of lactation failure in this population, a convenience (2001) survey of mothers of preterm infants providing breast milk for their babies was carried out. Fifty-five percent of these mothers had experienced lactation failure, several of whom had been prescribed domperidone (domperidone is not prescribed routinely in this centre). Therefore, 2023 women a year will be eligible for the study. Recruitment rates for research studies in our NICU range from 60-100 percent. Based on previous studies done in this setting where risk is minimal and side effects are rare, we estimate a greater than 90 percent recruitment rate.

\section{Will compliance be a concern?}

Since side effects are rare, we do not anticipate problems with compliance. The majority of mothers will be visiting their baby on a regular basis, hence providing milk and blood samples should not be a great inconvenience. Participants will receive their 2 -week supply of domperidone or placebo following enrollment. They will be provided with instruction related to self-administration and asked to return the medication vial and any unused medication at the completion of the two-week period. Pill counts will be done in pharmacy to ensure drug accountability and evaluate compliance. The study nurse/investigators will be in close contact with the mothers and review instruction related to medication on study days 4, 7 and 14 .

Based on our past clinical observations, we anticipate that the majority of the participants enrolled will be mothers of infants delivered between 24-28 weeks gestational age. The infants will be 29-33 weeks corrected gestational age at the end of the study period. Although many of these infants will receive skin to skin care from their mothers (kangaroo care), few will be actively breast feeding. For those infants who are enrolled at a later gestational age (who will be closer to 35 weeks at the end of the study period) and able to begin breast-feeding, milk volumes will be calculated using pre and post feeding weights. Mothers will be asked to refrain from breast-feeding and to express breast milk on days $0,4,7$ and 14 as per our usual practice to ensure that a 24 -hour pooled breast milk sample will be obtained. Recruitment and compliance therefore will not be adversely affected.

\section{What is the likely rate of loss to follow Up?}

The Neonatal Intensive Care Unit (NICU) is the tertiary level neonatal unit for all of Nova Scotia and for most of the Maritime Provinces. Most babies in the NICU stay until discharged from hospital. Approximately 20 percent return to local hospitals prior to discharge home. However, very few are transferred prior to 35 weeks corrected gestational age. Mothers of any infants transferred prior to discharge will be provided with a toll free telephone number and instructed to notify the principal investigator or study nurse of their discharge home. Answers to followup questions will be obtained by telephone by either the principal investigator or study nurse. In addition, most infants that meet inclusion criteria for this study (all Nova Scotia and Prince Edward Island babies born at less than 31 weeks) continue to be followed until three years of age as part of the IWK Perinatal Follow-up Program. This program loses two to three percent to follow-up. We therefore do not expect any significant losses to follow up.

\section{What is the proposed type and frequency of analysis? \\ a. Method of breast milk collection}

Throughout the study, breast milk will be expressed according to the standard practice of the nursery. Breast milk will collected using the Symphony reusable breast pump (Medela Canada). Each participant will be supplied with a double pump collecting system and sterile collection bottles. Each woman will be instructed to collect 24- 
hour samples of breast milk for the day prior to beginning treatment and then each day for the two-week period. A new container will be used for each pumping. Each participant will keep a diary to record the amount of milk pumped, the date and time as well as ensure that adhesive labels with this information also be placed on each of the containers. Daily milk volumes will be calculated. On days $0,4,7$ and 14 , two small samples ( $1 \mathrm{ml}$ and $30 \mathrm{mls}$ ) of milk (from a pooled 24 hour collection) will be retained for analysis. The remainder of the milk will be available for the infant as usual.

\section{b. Chemical analysis}

Breast milk samples ( $24 \mathrm{~h}$ - pooled) will be frozen ( $-70 \mathrm{C})$ and couriered in batches of eight for analysis of macronutrient content to the Prince Edward Island Food Technology Centre. Total nitrogen will be determined using the Kjeldahl method [75]; fat by the Roese-Gottlib method; ash and moisture by Forced Air Oven: and, energy, carbohydrate and lactose concentrations will be calculated [78].

Mineral content will be analyzed at the IWK Laboratory Department. Samples will be centrifuged and the aqueous component assayed [79]. Phosphorous content will be measured using the Ammonium molybdate method on the Ortho Vitros ${ }^{\circledast}$ ) chemistry analyzer [80]. Calcium content will be determined using the Arseno (III) method on the Ortho Vitros ${ }^{\varpi}$ ) chemistry analyzer [81]. Sodium content will be determined by ion selective electrode [82].

Mothers will also be asked to provide blood samples to determine prolactin concentrations prior to the initial dose, on day four and day 14. Serum prolactin levels will be collected at the IWK Health Centre outpatient tab and measured using Chemiluminescence immunoassay on the Vitros ${ }^{\circledast}$ ) Eci analyzer [83]. Each participant will receive, requisitions for blood collection dated for the appropriate study days required. If a participant is unable to come to the IWK Health Centre, the principle investigator or study nurse will make alternate arrangements with her family doctor and local laboratory to ensure that the specimen is collected.

\section{c. Statistical analysis}

Analysis and inference will be based on the intention-totreat principle. Efforts will be made to ensure that follow up is complete for all subjects and that there are no missing values for any of the subjects for any variable. Blinding of group assignment will be retained until after the analysis is completed. Baseline characteristics of study subjects will be contrasted to ascertain that randomization has in fact produced comparable groups with respect to all variables that effect the composition of breast milk including gestational age at delivery and duration since delivery. The primary outcome of interest will be a potential decline in breast milk protein content over time within the domperidone group versus the placebo group. This analysis will compare the means in the two groups before and after treatment and contrast the mean difference between groups using 95 percent confidence intervals and a p value. The stratified nature of the randomization will be accounted for in the analysis. If differences are noted in baseline characteristics, inferences will be made based on observed and (linear regression) adjusted differences between groups. Analysis for fat, lactose, energy, calcium, phosphorus and sodium content in expressed breast milk will be done in an identical fashion as for protein by comparing the means in the two groups before and after treatment and contrasting the mean differences between groups using 95 percent confidence intervals and a $\mathrm{p}$ value. Prolactin levels will be compared between the two groups and used to determine the correlation between prolactin levels and volume of milk produced.

\section{Trial management}

The study nurse will assume the role of study coordinator. She will be responsible for the day-to-day management of the trial. The principal investigator will have an active role in the trial and meet weekly with the study nurse.

\section{Significance of study}

To date, researchers have analyzed the effects of domperidone on lactating woman with respect to the quantity of their milk production, adverse effects, and drug levels in the breast milk. Currently, guidelines for fortification of human milk for preterm infants do not distinguish between women using or not using domperidone. Domperidone causes an increase in maternal prolactin levels and has been shown to significantly increase human breast milk volumes. No study has examined the effect of domperidone use (to augment lactation) on the composition of breast milk. The purpose of this study is to compare the macronutrient and macro mineral composition of breast milk between mothers of infants delivered at less than 31 weeks gestation, receiving domperidone versus placebo. If significant differences in nutrient content occur between groups, alterations to current standards of feeding practices for premature infants may need to be made in order to optimize growth and nutrition. The results of this study will provide clinicians with valuable information to aid in guiding feeding practices for preterm infants.

\section{Potential risks to the safety of participants involved in the study a. Potential side effects of medication}

Side effects associated with the use of oral domperidone are extremely uncommon. Side effects that have been reported include dry mouth, transient skin rash or itching, headache, thirst, abdominal cramps, diarrhea, drowsiness 
and nervousness. These side effects have been reported only occasionally (incidentally) and have been generally associated with high dosages of the medication. Symptoms are usually minor and all symptoms disappear following discontinuation of the medication $[41,76]$.

Domperidone is highly metabolized by CYP3A4 in the liver, drug interactions related to its inhibition are expected to occur. Cimetidine, ranitidine, famotidine, and nizatidine may interfere with domperidone's bioavailability and should not be co-administered [76]. Medications such as haloperidol and lithium when taken at the same time as domperidone may cause exaggerated central nervous system symptoms. Therefore, subjects who satisfy eligibility criteria will not be invited to participate in this study if they are taking any of these medications [76].

Low levels of domperidone are excreted in human breast milk [36,38]. There are no reported cases of side effects in infants. As previously mentioned, the Canadian and American Academy of Pediatrics have approved its use in breastfeeding mothers [41].

\section{b. Confidentiality}

Participant data collected during this trial will be kept confidential and locked in a secure office area. Study staff will have access to the data as well as participant's medical records as they pertain to this study. A letter will be sent to the participant's family doctor to inform him/her of their participation in the study. Published results will not contain any information that would identify individual participants. Study records will be stored in a locked area and will be kept for 10 years past the age of majority of the infant.

\section{Role of each investigator}

MCY will be responsible for the progress and timely completion of the trial. MCY, ACA, VMA and JML will be responsible for responding to clinical queries, encouraging recruitment, protocol compliance and accurate and complete data collection. KCD will be responsible for laboratory related queries. VMA will be responsible for prescribing medication and for providing advice regarding participant's concerns or questions. ACA will be responsible for providing advice regarding neonatal issues. KSJ will be responsible for providing advice on methodological issues and assisting with interpreting statistical analysis. Study investigators will be obliged to participate in study committee meetings related to study progress and completion.

\section{Ethics}

Informed consent will be obtained from the women prior to study entry. The IWK Health Centre Research Ethics Board has approved this study. Domperidone is consid- ered safe for use in lactating women. Nevertheless, a careful watch will be kept on all study participates with regard to side effects of drug administration. Participants will be made aware of possible side effects and given contact numbers in the event they experience an adverse effect. The research nurse or a member of the research team will ask each participant if they are experiencing any possible side effects on day 4, 7, and 14 of the study when breast milk samples are collected. Infants will be monitored as per the Neonatal Intensive Care Unit standard of care and their clinical condition will be evaluated daily as part of medical rounds.

The current standard of care at the IWK Health Centre Neonatal Intensive Care Unit does not recommend pharmacological management for lactation failure. The use of domperidone is based on the individual management practices of each woman's physician. There will be no study restrictions regarding the continued use of domperidone following the two-week study period. Any decision to do so would occur based on discussions between the participant and her family doctor. A letter informing the participant and the family doctor which study arm the participant had been randomized to will be sent following completion of the study.

\section{Study timeline}

The initial preparation time for this study will be two weeks. During that time, information will be given to the staff of the Neonatal Intensive Care Unit regarding study protocol. Approximately 60 infants less than 31 weeks gestation are admitted to IWK yearly. Of these 20-25 percent are multiples. Breast-feeding initiation rates are $80-$ 85 percent in our nursery. If half of these women experience difficulty with breast milk supply, 20-23 women a year will be eligible for the study. Recruitment rates are expected to be greater than 90 percent. Subject accrual and data collection will extend over 24 months. It will take an additional 4 months to analyze the data and prepare a manuscript. The study results will be widely disseminated through conference proceedings and peer reviewed publication. The total duration of the study is expected to be 28 months.

\section{Discussion}

The first participant was enrolled in October 2003. In June of 2004 a Food and Drug administration (FDA, U.S.A.) warning was issued regarding safety concerns related to domperidone and lactating women. Seven women had been enrolled at that time. The IWK Health Centre Research Ethics Board was informed of the FDA warning and enrollment was discontinued. A No Objection Letter regarding the trial (Control \# 093770) was issued by Health Canada October 1, 2004 and Ethics Approval was reinstated on October 5, 2004. An addendum was made 
to the consent form outlining the concerns raised by the FDA.

The FDA warning against the use of domperidone by lactating women was based on case reports related to the increased risk of cardiac arrhythmia and sudden death in patients with malignant disease receiving high-dose intravenous domperidone therapy concurrently with chemotherapy and experiencing hypokalemia (serum potassium levels between 2.0 and $3.3 \mathrm{mmol} / \mathrm{L}$ ). In its oral form, domperidone has been approved for use in Canada and worldwide as a motility agent with an excellent safety record. In a randomized trial, DaSilva et al determined that in women receiving $10 \mathrm{mg}$ of domperidone 3 times daily to enhance lactation, the mean serum level on day 5 of therapy was $6.6 \mathrm{ng} / \mathrm{mL}$ [17]. The mean level of domperidone excreted in the breast milk of these women was $1.2 \mathrm{ng} / \mathrm{mL}$. No adverse effects to either mother or infants were reported.

\section{Competing interests}

The author(s) declare that they have no competing interests.

\section{Authors' contributions}

All authors contributed to the development of the proto$\mathrm{col}$, and read and approved the final manuscript.

\section{Acknowledgements}

The authors would like to acknowledge Kim Caddell for her tremendous organization and management of the study; the mothers and infants who have participated in the study to date; and, the staff of the NICU for their support. The authors would also like to thank Medela Canada for their support related to breast pumps and supplies. Funding for the study was obtained through partnered funding from the Canadian Nurses Foundation, Nursing Care Partnership; IWK Health Centre Research Services; and Dalhousie University Nursing Research Fund.

\section{References}

I. American Academy of Pediatrics, Work Group on Breastfeeding: Breastfeeding and the use of human milk. Pediatrics 1997, 100:1035-1039.

2. Canadian Pediatric Society clinical practice guidelines: Nutrition for healthy term infants. J Paediatr Child Health 1998, 3: I09-II2.

3. Schanler RJ, Hurst NM: Human milk for the hospitalized preterm infant. Semin Perinatol 1994, 18:476-486.

4. Schanler RJ, Shulman RJ, Lau C: Feeding strategies for preterm infants: beneficial outcomes feeding fortified milk versus preterm formula. Pediatrics 1999, I03: I I50-II57.

5. Nutrition Committee, Canadian Paediatric Society: Nutrient needs and feeding of premature infants. Can Med Assoc J 1995, I 52: 1765-1784.

6. Tudehope DI, Steer PA: Which milk for preterm infants ? J Paediatr Child Health 1996, 32:275-277.

7. Kuschel CA, Harding JE: Multi-component fortified human milk for promoting growth in preterm infants (Cochrane Review). In The Cochrane Library Issue 4 Oxford: Update Software; 2000.

8. Ehrenkranz RA, Ackerman BA: Metoclopramide effect on faltering milk production by mothers of premature infants. Pediatrics 1886, 78:614-620.

9. Brogden RN, Carmine AA, Heel RC, Speight TM, Avery GS: Domperidone: A review of its pharmacological activity, pharmok- inectics and therapeutic efficacy in the symptomatic treatment of chronic dyspepsia and as an antimetic. Drugs 1982, 24:360-400.

10. Kauppila A, Kivinen S, Ylikorkala O: A dose response relation between improved lactation and metoclopramide. Lancet 1981, I:I I 775-1177.

II. Gupta AP, Gupta PK: Metoclopramide as a lactogogue. Clin Pediatr 1985, 24:269-272.

12. Kauppila A, Arvela P, Koivisto M, Kivinen O, Ylikorkala O, Pelkonen : Metoclopramide and breast feeding: Transfer into milk and the newborn. Eur J Clin Pharmacol 1983, 25:819-823.

13. Budd SC, Erdman SH, Long DM, Trombley SK, Udall JN: Improved lactation with metoclopramide. Clin Pediatr 1993, 32:53-57.

14. Lewis PJ, Devenish C, Kahn C: Controlled trial of metoclopramide in the initiation of breast-feeding. Br J Clin Pharmacol 1980, 9:217-219.

15. Hofmeyer GJ, Van Iddekinge B, Blott JA: Domperidone: Secretion in breast milk and effect on puerperal prolactin levels. $B r J$ Obstet Gynaecol 1985, 92:141-144.

16. Hofmeyer G, Brouwers J, Westhuis T: Domperidone and Lactation. Lancet 1983, I:647.

17. Da Silva OP, Knoppert DC, Angelili MM, Forret PA: Effect of domperidone on milk production in mothers of premature newborns: a randomized, double-blind, placebo-controlled trial. Can Med Assoc J 200I, 164:17-2I.

18. Petraglia F, De Leo V, Sardelli S, Pieroni ML, D'Antona N, Genazzani AR: Domperidone in defective and insufficient lactation. Eur J Obstet Gynecol Reprod Biol 1985, I 9(5):28I-7.

19. de Gezelle H, Ooghe W, Thiery Dhont M: Metoclopramide and breast milk. Eur J Obstet Gynecol Reprod Biol 1983, I 5:31-36.

20. Ertl T, Sulyok E, Nemeth M: Hormonal control of sodium content in human milk. Acta Paediatr Acad Sci Hung 1982, 23:309.

21. Ertl T, Sulyok E, Ezer E, Sarkany I, Thurzo V: The influence of metaclopramide on the composition of human breast milk. Acta Paediatr Hung 1991, 3 I:415-422.

22. Lawrence R: Breastfeeding: A guide for the medical professional 5 th edition. St. Louis, MO: Mosby, Inc; 1992:95-158.

23. Ellard $D$ : Optimizing nutritional management for the very low-birth weight infant. Nutr Clin Pract 200I, 16:240-245.

24. Ogra PL, Rassin DK: Human breast milk. In Infectious diseases of the fetus and newborn infant 4th edition. Edited by: Remington JS, Klein JO. Philadelphia: WB Saunders; 1995: 108-139.

25. Delneri MT, Carbone SB, Silva ML, Palmeira P, Carneiro-Sampaio MM: Inhibition of enter pathogenic escherichia coli to Hep-2 cells by colostrum and milk from mothers delivering lowbirth weight neonates. Eur J Pediatr 1997, 156:493-498.

26. Scariati PD, Grummer-Strawn LM, Fein SB: A longitudinal analysis of infant morbidity and the extent of breastfeeding in the United States. Pediatrics 1997, 99:E5.

27. Hylander MA, Strobino DM, Dhanireddy R: Human milk feedings and infection among low birth weight infants. Pediatrics 1998 , 102:e38.

28. Kramer MS, Chalmers B, Hodnett ED, Sevkovskaya Z, Dzikovich I, Shapiro S, Collet JP, Vanilovich I, Mezen I, Ducruet T, Shishko G, Zubovich V, Mknuik D, Gluchanina E, Dombrovskiy V, Ustinovitch A, Kot T, Bogdanovich N, Ovchinikova L, Helsing E, PROBIT Study Group (Promotion of Breastfeeding Intervention Trial): A randomized trial in the Republic of Belarus. JAMA 200I, 285:4|3-420.

29. Lucas A, Morley R, Cole TJ, Lister G, Leeson PC: Breast milk and subsequent intelligence quotient in children born preterm. Lancet 1992, 339:261-264.

30. Morley R, Lucas A: Influence of early diet on outcome in preterm infants. Acta Paediatr Suppl 1994, 405: 123-1 26.

31. Lucas A, Morley R, Cole TJ, Gore SM: A randomized study of human milk versus formula and later development in preterm infants. Arch Dis Child 1994, 70:FI4I-6.

32. Rogan WJ, Gladen BC: Breast-feeding and cognitive development. Early Hum Dev 1994, 3 1: 181.

33. Chatterton RT, Hill PD, Aldag JC, Belknap SM, Jinman MJ: Relation of plasma oxytocin and prolactin concentration to milk production in mothers of preterm infants: influence of stress. J Clin Endocrinol Metab 2000, 85:366I-3668.

34. Aono T, Shioji T, Shoda T, Kurachi K: The initiation of human lactation and prolactin response to suckling. J Clin Endocrinol Metab 1997, 4:1101-II06. 
35. Fuchs A: Physiology and endocrinology of lactation. In Obstetrics, Normal and Problem Pregnancies 3rd edition. Edited by: Gabbe S, Niebyl R, Simpson JL. New York: Churchill Livingstone; 1999:137-I57.

36. Lefrak L, Dowling D: Nutrition: physiologic basis of metabolism and management of enteral and parenteral nutrition. In Comprehensive Neonatal Nursing 2nd edition. Edited by: Kenner C, Lett J, Flaundermeyer A. Philadelphia: WB Saunders Co; 1998:345-370.

37. Hill PD, Aldag JC, Chatterton RT: The effect of sequential and simultaneous breast pumping on milk volume and prolactin levels: a pilot study. J Hum Lact 1996, I 2:193-199.

38. Engel JA, Lundborg AA: Behavioral and biochemical effects in offspring of nursing rats exposed to dopamine receptor antagonists. Vol I of 13th Congress of the Collegium Internationale NeuroPsychopharmacologicum 1982, 22:198.

39. Laduron P, Leysen J: Domperidone: as specific in vitro dopamine-antagonist devoid of in vitro ventral dopaminger activity. Biochem Pharmacol 1979, 28:216I-2167.

40. Brouwers J, Assies J, Wiersings WM, Huizing G, Tytgat G: Plasma prolactin levels after acute and sub chronic oral administration of domperidone and of metoclopramide: A cross over study in healthy volunteers. Clin Endocrinol 1980, I 2:435-440.

4I. Hale T: Medication and Mother's 9th edition. Milk Texas: Pharmasoft Medical Pub; 2000

42. Atkinson SA, Bryan MH, Anderson G: Human milk feeding in premature infants: Protein, fat, and carbohydrate balances in the first two weeks of life. J Pediatr 198I, 99:617-624.

43. Atkinson SA, Radde IC, Anderson GH: Macro mineral balances in premature infants fed their own mother's milk or formula. Pediatr 1983, 102:99-106.

44. Brooke OG, Onubogu O, Heath R, Carter ND: Human milk and preterm formula compared for effects on growth and metabolism. Arch Dis Child 1987, 62:917-923.

45. Cooper PA, Rothberg AD, Pettifor JM, Bolton KD, Devenhuis S: Growth and biochemical response of premature infants fed pooled preterm milk or special formula. J Pediatr Gastroenterol Nutr 1984, 3:749-54.

46. Davies DP: Adequacy of expressed breast milk for early growth of preterm infants. Arch Dis Child 1997, 52:296-30I.

47. De Curtis M, Brooke OG: Energy and nitrogen balances in very low birth weight infants. Arch Dis Child 1987, 62:830-832.

48. Gross S]: Growth and biochemical responses of preterm infants fed human milk or modified infant formula. $N$ Engl J Med 1983, 308:237-24I.

49. Kashyap S, Schulze KF, Forsyth M, Dell RB, Ramakrishnan R, Heird WC: Growth, nutrient retention, and metabolic response of low-birth-weight infants fed supplemented and unsupplemented preterm human milk. Am J Clin Nutr 1990, 52:254-262.

50. Tonz O, Schubiger G: Feeding of very-low-weight infants with breast-milk enriched by energy, nitrogen and minerals. Helv Paediatr Acta 1985, 40:235-247.

51. Quan R, Yang C, Rubinstein S, Lewiston NJ, Stevenson DK, Kerner JA Jr: The effect of nutritional additives on anti-infective factors in human milk. Clin Pediatr 1994, 33:325-328.

52. Gross SJ, David RJ, Bauman L, Tomarelli RM: Nutritional composition of milk produced by mother delivering preterm. J Pediatr 1980, 96:64|-644.

53. Lawrence R: Breastfeeding: A guide for the medical professional 5th edition. St. Loius: Mosby Inc; 1999:95-I58.

54. Lucas A, Fewtress MS, Morley R, Lucas PJ, Baker BA, Lister G, Bishop $\mathrm{N}$ ): Randomized outcome trial of human milk fortification and developmental outcome in preterm infants. Am J Clin Nutr 1996, 64:|42-|15|.

55. Abrams SA, Schanler RJ, Garza C: Bone mineralization in former very low birth weight infants fed either human milk or commercial formula. J Pediatr 1988, I I 2:956-962.

56. Abrams SA, Schanler RJ, Tsang RC, Garza C: Bone mineralization in former very low birth weight infants fed either human milk or commercial formula: One year follow-up observation. J Pediatr 1989, I | 4: 104I-1044

57. Kumar SP, Sacks LM: Hyponatremia in very low-birth weight infants and human milk feedings. J Pediatr 1978, 93:1026-1027.

58. Lucas A, Brooke OG, Baker BA, Bishop N, Morley R: High alkaline phosphates activity and growth in preterm neonates. Arch Dis Child 1989, 64:902-909.
59. Lawrence R: Breastfeeding: A guide for the medical professional 5th edition. St. Louis: Mosby Inc; 1999:95-158.

60. Schanler RJ, Abrams SA: Postnatal attainment of intrauterine macromineral accretion rates in low birth weight infants fed fortified human milk. J Pediatr 1995, I 26(3):44I-7.

6I. Schanler RJ, Garza C: Improved mineral balance in very low birth weight infants fed fortified human milk. J Pediatr 1987 , I I 2:452-456

62. Kuschel CA, Harding JE: Protein supplementation of human milk for promoting growth in preterm infants (Cochrane Review). In The Cochrane Library Issue 4 Oxford: Update Software; 2000

63. Atkinson S: Effects of gestational stage at delivery on human milk composition. In Handbook of Milk Composition Academic Press Inc; 1995:222-237.

64. Paul, Vinod K, Singh M, Srivastaeva LM, Arora NK, Deorari AK: Macronutrient and energy content of breast milk of mothers delivering prematurely. Indian J Pediatr 1987, 64:379-382.

65. Hibberd CM, Brooke OG, Carter ND, Haug M, Harzer G: Variation in the composition of breast milk during the first 5 weeks of lactation: Implications for the feeding of preterm infants. Arch Dis Child 1989, 57:658-62.

66. Neville MC, Keller RP, Seacat J, Casey CE, Alen JC, Archer P: Studies on human lactation: Within-feed and between-breast variation in selected components of human milk. Am J Clin Nutr 40:635-646.

67. Anderson GH, Atkinson SA, Bryan MH: Energy and macronutrient content of human milk during early lactation from mothers giving birth prematurely and at term. Am J Clin Nutr 198I, 34:258-265.

68. Britton JR: Milk protein quality in mothers delivering prematurely: Implications for infants in the intensive care unit nursery setting. J Pediatr Gastroenterol Nutr 1986, 5: I I6-12I.

69. Gross S], David RJ, Bauman L, Tomarelli RM: Nutritional composition of milk produced by mothers delivering preterm. J Pediatr 1980, 96:64I-4.

70. Gross S], Geller J, Tomarelli RM: Composition of breast milk from mothers of preterm infants. Pediatrics 1981, 68:490-493.

71. Lemons JA, Moye L, Hall D, Simmons M: Differences in the composition of preterm and term milk during early lactation. Pediatr Res 1982, 16:1 I3-1 I7

72. Schanler RJ, Oh W: Composition of breast milk obtained from mothers of premature infants as compared to breast milk obtained from donors. J Pediatr 1980, 96:678-68I.

73. Anderson DM, Williams FH, Mekatz RB, Schulman PK, Kerr DS, Pittard WB: Length of gestation and nutritional composition of human milk. Am J Clin Nutr 1983, 37:8I0-8I4.

74. Maas Y, Gerriten J, Hart A, Hadders-Algra M, Ruijter J, Tamminga P, Mirmiran M, Spekreijse H: Development of marconutrient composition of very preterm human milk. Br J Nutr 1998, 80:35-40

75. Atkinson SA, Bryan MH, Anderson GH: Human milk: Difference in nitrogen concentration in milk from mothers of term and premature infants. J Pediatr 1978, 93:67-9.

76. Anderson PO, Knoben JE, Troutman WG: Handbook of Clinical Drug Data 9th edition. Standford, Conn.: Appleton Lange; 1999:535-538.

77. Helrich K: Official Methods of Analysis of the AOAC 15th edition. Arlington, VA: Association of Official Analytical Chemists; 1999.

78. Kunz C, Rodriguez-Palmero M, Koletzko B, Jensen R: Nutritional and Biochemical properties of human milk, Part I: General Aspects, Proteins and Carbohydrates. Clin Perinatol 1999, 26,:307-333.

79. Georgewill DA, Graham GA, Schoen I: Applicability of the Ekatachem $\mathbf{4 0 0}$ analyzer for assaying analytics in miscellaneous body fluids. Clin Chem 1988, 34:2534-2539.

80. Warty V, Chilcott J, Soncini V, Seltman H, Sanghvi A, Evans L: EktaChem assay for phosphorus evaluated. Clin Chem 1985 , 31:495-496.

8I. Goodman DB, Erickson K: Stability of total calcium as determined by using Kodak Ektachem dry-film methodology. Clin Chem 1988, 34:600-601.

82. Costello P, Kubasik NP, Brody BB, Sine HE, Bertsch JA, D'Souza JP: Multilayer film analysis: evaluation of ion-selective electrolyte slides. Clin Chem 1983, 29:129-32.

83. Saw S, Sethi S: Technical evaluation of thyroid assays on the Vitros Eci. Clin Chem 1999, 45:578-80. 
84. Gabay M: Galactogogues: Medications that induce lactation. J Hum Lact 2002, 18:274-279.

\section{Pre-publication history}

The pre-publication history for this paper can be accessed here:

http://www.biomedcentral.com/1471-2393/6/17/prepub

Publish with Biomed Central and every scientist can read your work free of charge

"BioMed Central will be the most significant development for disseminating the results of biomedical research in our lifetime. " Sir Paul Nurse, Cancer Research UK

Your research papers will be:

- available free of charge to the entire biomedical community

- peer reviewed and published immediately upon acceptance

- cited in PubMed and archived on PubMed Central

- yours - you keep the copyright

Submit your manuscript here:

http://www.biomedcentral.com/info/publishing_adv.asp
BioMedcentral 